\title{
STRATEGY OF BUSINESS DIGITALIZATION OF MICRO, SMALL, AND MEDIUM ENTREPRISES (A CASE STUDY OF CULTIVE APPAREL)
}

\author{
Muhammad Faizurrohman ${ }^{* 1}$, Lukman M. Baga**), Siti Jahroh ${ }^{*}$ \\ ${ }^{*}$ School of Business, IPB University \\ Jl. Pajajaran, Bogor 16151, Indonesia \\ ${ }^{* *}$ Department of Agribusiness, Faculty of Economics and Management, IPB University \\ Jl. Agatis, IPB Darmaga Campus, Bogor 16680, Indonesia
}

\begin{abstract}
Transformation needs to be carried out by various scales of business including Micro, Small and Medium Enterprises (MSMEs). Cultive Apparel is one of the clothing MSMEs that has experienced a decline in business performance since digital development. This study aims to analyze the causes of the gap between actual and expected conditions, identify and map business environmental factors, and formulate digital business strategies. Data analysis use spider web, IFE and EFE analysis (PESTEL and 5 Forces Porter), IE matrix, and QSPM Matrix. The results show a gap in the lack of product promotion activities in the digital. The main strength lies in the product brands that are known by consumers. The biggest weakness is the limited human resources. The greatest opportunities for a price match with suppliers and consumer loyalty. The biggest threat to suppliers who carry out direct retail sales to consumers and price wars. IE matrix shows the company is in quadrant II. Strategies that can be carried out in this quadrant are intensive and integrative strategies. QSPM matrix showed that the company should develop the market. Managerial implications are carried out by improving digital infrastructure, improving operational capabilities, developing market segments, and increasing the intensity of digital marketing.
\end{abstract}

Keywords: business digitalization, fashion, industry 4.0, market development

Abstrak: Upaya transformasi bisnis perlu dilakukan oleh berbagai sekala usaha termasuk Usaha Mikro, Kecil, dan Menengah (UMKM). Cultive Apparel merupakan salah satu UMKM pakaian yang mengalami penurunan performa bisnis sejak perkembangan era digital. Penelitian ini bertujuan untuk menganalisis penyebab terjadinya gap antara kondisi aktual dan harapan (target), mengidentifikasi dan memetakan faktor lingkungan yang memengaruhi bisnis, menyusun strategi formulasi bisnis digital yang sesuai. Teknik pengolahan dan analisis data menggunakan spider web, analisis IFE dan EFE (PESTEL dan 5 Forces Porter), matriks IE, dan matriks QSPM. Hasil analisis menunjukkan gap terbesar pada minimnya kegiatan promosi produk di dunia digital. Analisis lingkungan menujukkan kekuatan utama terletak pada merek produk yang telah dikenal oleh konsumen. Kelemahan terbesar pada keterbatasan sumberdaya manusia. Peluang terbesar pada kesesuaian harga dengan pemasok dan loyalitas konsumen. Ancaman terbesar pada pemasok yang melakukan penjualan langsung secara ritel kepada konsumen dan terjadinya perang harga. Matriks IE menunjukkan perusahaan berada di kuadran II. Matriks QSPM menunjukkan perusahaan harus melakukan pengembangan pasar. Strategi yang dapat dilakukan perusahaan dalam kuadran ini adalah strategi intensif dan integratif. Implikasi manajerial dilakukan dengan meningkatkan infrastruktur digital, meningkatkan kemampuan operasional karyawan, mengembangkan segmen pasar, dan meningkatkan intensitas pemasaran digital.

Kata kunci: industri 4.0, pengembangan pasar, fashion, digitalisasi bisnis

\footnotetext{
${ }^{1}$ Corresponding author:

Email: faizurrohmanmuhammad@gmail.com
} 


\section{INTRODUCTION}

The existence of the internet has triggered the rapid development of industry 4.0. The internet has managed to arouse public interest in digital transactions (online). Various digital business platforms have emerged to respond to these developments, such as e-commerce and social media. The role of e-commerce and social media in the development of business in Indonesia today is quite important especially as marketing media. Based on Data Sharing Vision, the value of e-commerce transactions in Indonesia grows $39.6 \%$ per year. In 2020 , it is predicted that the transaction will reach IDR562 trillion and will touch IDR1,000 trillion. The high level of millennial interest in the use of gadgets is one of the drivers of the rapid development of digital businesses. According to the Minister of Trade, currently the phenomenon of online shopping has been rife in Indonesia, for this reason he suggested that the offline world entrepreneurs strengthen the synergy with the digital world. According to him, business players who can survive the disruptive situation are those who have adjusted to meet market demand, especially millennials (Kencana, 2018).

The growth of e-commerce in Indonesia is quite rapid. The percentage of Indonesian people who buy goods and services online within one month in 2017 reached $41 \%$ and the total population of Indonesia. This number has continued to increase from 2015 which ranged from less than $11 \%$ to $26 \%$ in 2016 . Thus there has been an increase in users of online transactions by $15 \%$ in one year. According to the Indonesian Retailers' Association (APRINDO), the internet has changed people's spending patterns. Some retail outlets stop operating and as many as 50 others will stop operating. ShopBack survey results indicate that of the 1000 respondents, as many as $70.2 \%$ stated the existence of e-commerce greatly affects their shopping behavior. What's interesting about this behavior, as much as $83.1 \%$ claimed to have been to the offline market to view goods and then buy them online. This is due to the many discount promotions offered on e-commerce platforms. Another thing offered by e-commerce is the convenience of shopping without having to be limited by time and space, because through the internet consumers can buy goods at any time wherever they are (Barlian, 2018).
Aside from being done by large companies, efforts to transform business in the face of industry 4.0 also need to be done by small and medium-sized entrepreneurs (MSMEs). MSMEs have become one of the drivers of the community's economy because they are able to absorb labor, reduce unemployment and empower the community. The existence of e-commerce increasingly weakens the performance of conventional MSMEs. Some MSMEs are forced to close down because it has been eroded by the swift flow of digital currents. The decreasing number of conventional MSMEs can have a negative impact on the decline in the economy of the community, especially the lower middle class and on the changing culture of the community. Seeing the important role of MSMEs in the life of the community, it is necessary to make various efforts to maintain its existence (Rachmana, 2019).

The Ministry of Communication and Technology (Kominfo, 2017) declared that the clothing industry is one of the MSMEs industrial sectors which has a significant contribution to the economy. Until the end of 2019, MSMEs in the clothing or fashion sector provided a significant contribution to the creative industry economic sector, which amounted to $18 \%$ of state revenue. Meanwhile, the prediction of contribution growth of MSMEs is only estimated to reach $5 \%$ of the online platform sector. This is consistent with the estimated economic growth in the range of $5-5.2 \%$. In that year, MSMEs got a boost in the consumption of food, beverages and clothing which was expected to be quite high.

Idah and Pinilih (2019) conveyed that based on the calculation of the digital-based IFE and EFE matrix, Indonesian MSMEs are currently in quadrant I, so that the priority strategies used to develop the digitization of MSMEs are increasing market share, adding production units and improving product quality, and improving the process online marketing. Meanwhile, a digital development strategy for SMEs in the provision of ICT infrastructure, production processes, and market expansion in the short, medium and long term must be carried out so that MSMEs have competitiveness and can improve their performance (Slamet et al. 2016). Digital marketing has a positive and significant influence on consumer purchasing decisions. Promotional media with digital marketing is useful for consumers in getting easy information anytime and anywhere. 
According to Kuncoro and Santoso (2018), in marketing distribution products, it is necessary to determine the target market and marketing mix. Target setting is done to focus the company's resources on getting the appropriate target market. Meanwhile, the marketing mix needs to be focused on product and quality. Distro products need to be consistent to build a brand or company image. Meanwhile, promotion needs to be done through increasing promotions at certain moments to increase sales. Also, make sales through social media to display the company's products. Kholiq et al. (2017), adding that distro consumer satisfaction is significantly influenced by product quality, price, and location of purchase. Product innovation in business digitization can be improved by increasing customer orientation, competitor orientation and cross-functional coordination. Furthermore, higher product innovation will affect marketing performance and further increase sustainable competitive advantage.

Cultive Apparel is a business that is engaged in retail sales of clothing (fashion). Currently, the company is run by conventional methods by opening a shop located in Cikarang Selatan, Bekasi, West Java, Indonesia. This business turnover has decreased, especially at a time when e-commerce and various other online businesses are increasingly developing in 2018 (Figure 1).

Based on the data, revenue of Cultive Apparel started strated decline in 2018. Whereas, according to Katadata (2018), in that year Indonesia's e-commerce growth took the first position in the world, which was $78 \%$. This is mainly supported by the high number of internet users in Indonesia. Responding to this condition, the decline in revenue can happen due to still using conventional technology. This company has internal constraints such as low employee skills and conventional technology. From the external side, the company also experienced an increase in product purchase orders from suppliers, which resulted in increased costs. On the other hand, some suppliers also make sales that can reduce market share. Companies need to carry out digital transformation to keep up with the development of the business landscape. It can avoid risks resulting from incorrect identification and deployment of processes and resources, as well as decisions about which sustainability values, in addition to economic values, have strategic importance (Fadhilah et al. 2019; Rauter et al. 2017).
In this case, Cultive Apparel needs to be done by considering the actual conditions of the company and the targets to be achieved, the conditions of the business environment and implementing the best alternative strategies for the company in accordance with current conditions. Therefore, Cultive Apparel needs to innovate through a business transformation in the digital field so that it can adapt to changes in the business environment. Using the electronic media by SMEs is becoming prominent (Samuel and Sarprasatha, 2016; Shabbir et al. 2016). Implementation of modern digital tools allows sustainable development of SMEs (Gil-Gomes et al. 2020). So, the objectives of this study include analyzing the causes of the gap between actual conditions and expectations (targets), identifying and mapping environmental factors that affect the business, developing appropriate digital business formulation strategies. This result can also be a reference material to the others SMEMs that will be transforming into digitalization business.

\section{METHODS}

This research was conducted with a case study on Cultive Apparel located in Cikarang, Bekasi, West Java, Indonesia, from June to December 2020. Research using primary and secondary data. Primary data was obtained from observations, and interviews from various sources both internal and external. Other data collection techniques are literature studies, which examine various sources in order to obtain secondary data and information needed and complete the data obtained from interviews and observations that have been conducted. Sampling is done using non-probability sampling techniques (examples without opportunities), namely the determination of respondents deliberately (purposive sampling) through the expert judgment approach. The respondents used internally were the Cultive Apparel owners and the external respondents came from six fashion business owners who had implemented business digitalisation. The data analysis is done by identifying environmental factors within the company (internal) and the external environment of the company (external). Analyzes were performed with IFE and EFE matrices, IE Matrix, and also QSPM (Quantitative Strategic Planning Management) Matrix. The EFE matrix was analysed using PESTEL (Politics, Economic, Social, Technology, Environment, Legal) and 5 Forces Porter. 


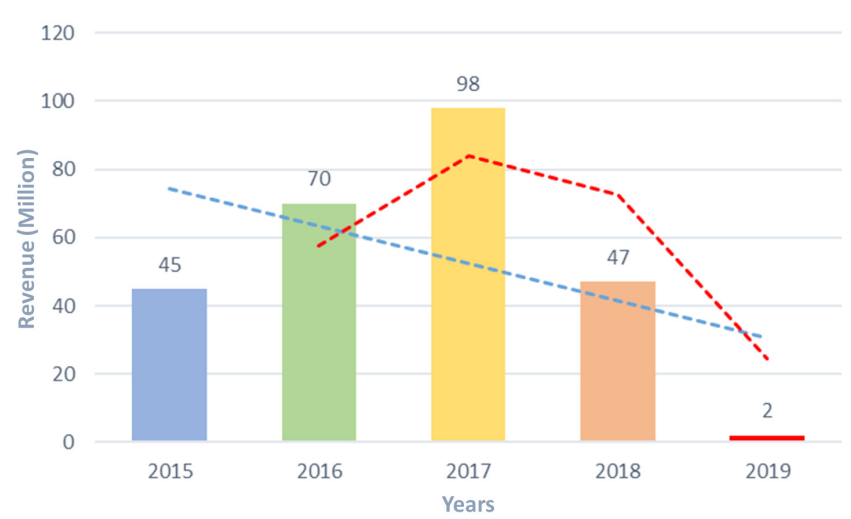

Figure 1. Trend of cultive apparel revenue, 2015 2019

Initial analysis was carried out with spider web analysis to determine gaps in the business aspects of the company. The results obtained will be a reference for conducting an analysis of the company's business environment, particularly the internal environment. IFE and EFE analysis are used to identify the main factors in the strengths and weaknesses of the company as well as opportunities and threats from the business environment. In the EFE analysis, the 5 Forces Porter and PASTEL methods are used to comprehensively determine the business environment factors that have the greatest influence. The results obtained from IFE and EFE are then put into the IE matrix to determine the current position and condition of the company so that it can become the basis for making alternative business strategies. The various alternative strategies obtained were then selected using the QSPM matrix.

This research was initiated by a common problem experienced by MSMEs, namely the rapid development of digital businesses which caused conventional MSMEs to lose the competition. Along with these conditions, the income of MSMEs has decreased due to limited market share and is unable to compete in the field of digital technology. These various analytical tools are used based on the framework in this study (Figure 2).

\section{RESULTS}

\section{Gap Analysis}

Gap analysis is conducted to determine the various factors of gaps in actual conditions and targets to be achieved. Digital technology can be one of the factors for the occurrence of gaps (Astuti et al. 2020). Digitalization of MSMEs by making products following market demand can expand market reach. Meanwhile, Bismala (2016) revealed that in general, MSMEs have not implemented business strategies consistently, do not have specific marketing strategies and use human resources with minimal expertise. On average, MSMEs at convection companies do not use the principle of specialization of expertise because the work done tends to be focused on one job. Aina et al. (2017) added that individual factors also have a positive effect on online entrepreneurial behavior. Meanwhile, based on the results of the interview with the internal respondent, there are 5 (five) important factors that the company needs to pay attention to, namely market reach, IT facilities, service quality, promotional activities, and organizational management. The five factors are then analyzed in more depth based on the influencing variables, then an assessment is carried out using a Likert scale. The results of the assessment are then calculated for the prolonged value by reducing the average expected value (target) by the actual condition average value. The results of the gap analysis assessment on these five factors are shown in Figure 3.

Based on the gap analysis in Figure 3, the results show that the biggest gaps are promotion activities, IT facilities, market reach, organizational management, and finally service quality. Promotional activities get a gap score of 2.2. The magnitude of this gap value is influenced by the lack of promotional activities through online media. Based on the results of the analysis, five variables influence namely endorsement activities, discounts, implementation of promotions, selling price adjustments, and sales guarantees. Endorse activity is the variable that gets the highest gap score. This is because promotional and advertising activities using the services of celebrities or well-known figures to promote products are very rarely carried out by companies.

In the second factor, IT facilities, the gap value obtained is 2.0. The variable that most influences are the budget on the provision and use of IT facilities. Meanwhile, other variables are the lack of a number of IT equipment, quality of equipment, ability to operate and IT knowledge. The third factor is the market reach which has a gap value of 1.6. The most influencing variable is the way to reach the market, while the other variables are the clarity of the target market, the coverage area, how to manage the market, and the suitability of tastes to the market. The fourth factor is organizational management (0.8). The most influencing variable is HR expertise and other variables that influence are the 
number of human resources, operational costs, place of sale, and the quality of the products produced. The fifth factor is service quality (0.6). The most influencing variables are speed, mastery and communication, while the other variables are service friendliness, product mastery, and product display.
Each of the factors that become the Cultive Apparel gap then becomes the basis for the next analysis, namely the analysis of the business environment. The gaps that occur in the gap analysis are important information to reveal the extent of the company's internal business environment. In general, the occurrence of weakness is closely related to the weaknesses of the company. This will be clarified in the analysis of the internal business environment.

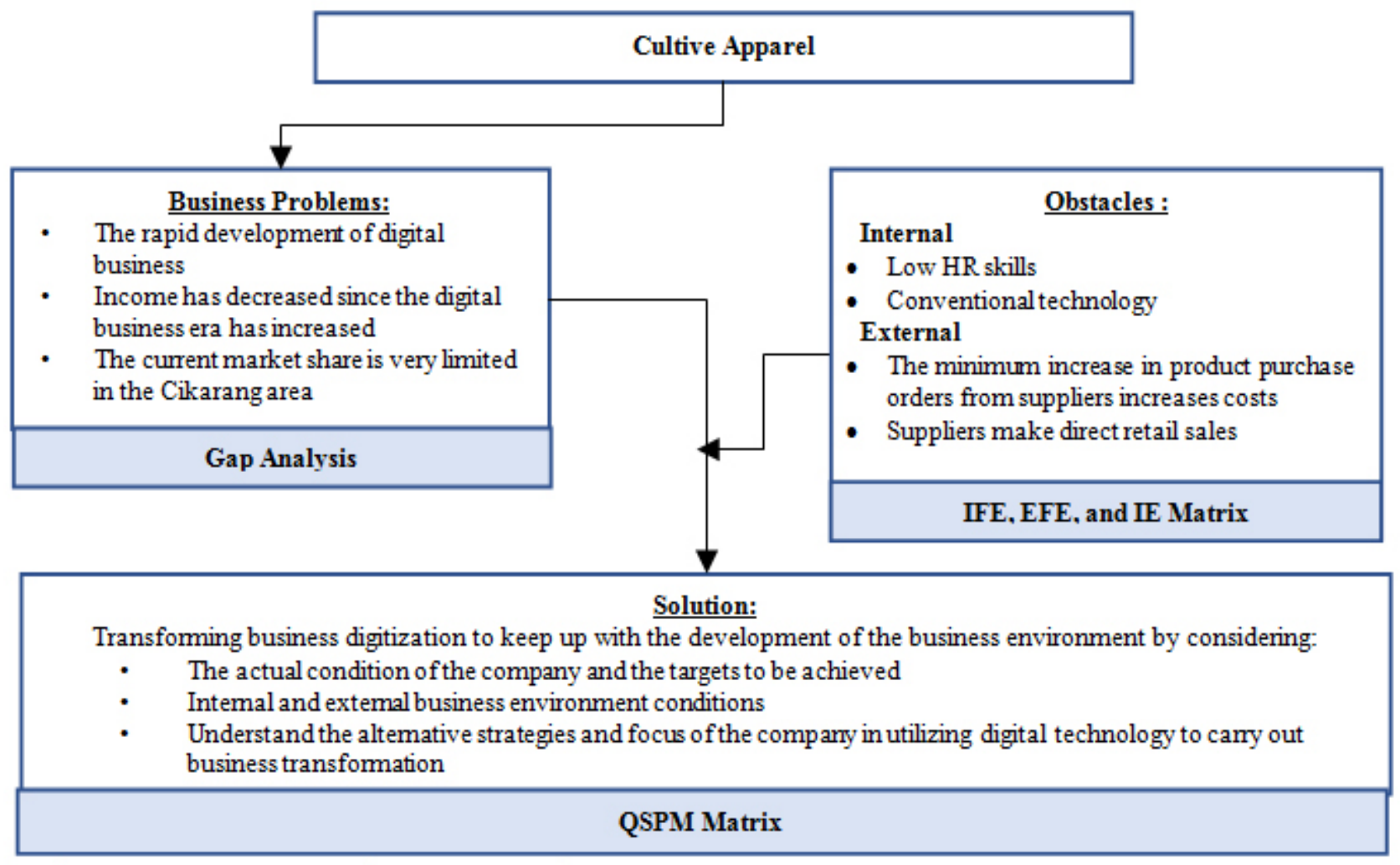

Figure 2. Research framework

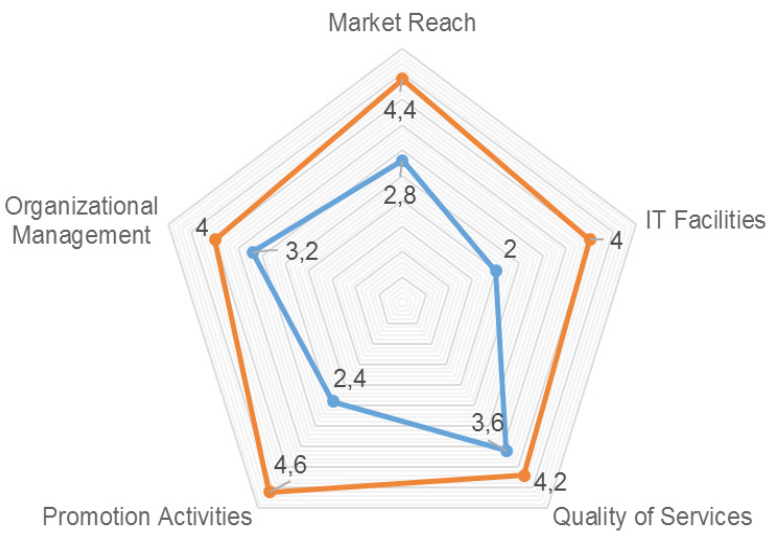

$\leadsto$ Actual Conditons $\leadsto$ Expectations

Figure 3. Gap analysis of cultive apparel 


\section{Internal Environmental Analysis}

The internal environment is the environment that is within the company and has direct implications for performance. The analysis begins by identifying the factors that influence the company's business internally. This is done in detail to see the resources that are the strengths and weaknesses of the company (David, 2009). Each variable is then assessed to see which variables are classified as strategic, namely those that have an impact on business development or have the ability to create distinctive competencies.

Based on the analysis results of the five major strengths of Cultive Apparel lies in the owner who is young, passionate and sincere, a brand that is well known to consumers, product traceability, focused target market and products, and a comfortable shopping place. Meanwhile, strategic factors that become weaknesses are unattractive visual content, erratic store opening/ closing times, limited human resources, overcoming performance problems, and limited use of the latest technology.

After obtaining the five influencing factors, the internal environmental analysis is then continued with the IFE (Internal Factors Analysis) Matrix Analysis. In this matrix, internal strategic factors are analyzed and assessed based on the concept of Wheelen and Hunger (2012), namely an assessment of internal strategic factors based on the product of weight and rating. The results of the IFE Matrix analysis obtained are shown in Table 1.

In Table 1, it can be seen that Cultive Apparel has an IFE value of 2.62, which means the company has moderate internal strength. This shows that the company is currently quite good at managing its internal resources, both in terms of strengths and weaknesses. The greatest strength is that some brands of goods can be marketed well by the owner of the producer (1.00). This power can be used to increase the attention of prospective buyers and increase product sales through digital media. Supplier brands that are better known to the public will make it easier for companies to introduce original products that are produced by Cultive Apparel (co-branding). Rahab (2009) states that co-branding or collaboration with other brands can promote other brands. Aghekyan (2009) revealed that there is a significant relationship between brands and buying interest in online clothes consumers. Meanwhile, the main weakness lies in the limited expertise of human resources $(0.06)$. The weaknesses identified in this analysis clarify the results of the gap analysis that was previously carried out. The gap that occurs in the lack of IT facilities, market reach, and corporate promotional activities is suspected by the company's weakness which lies in the company's limitations in using the latest technology and less attractive visual content.

Table 1. IFE Matrix of cultive apparel

\begin{tabular}{|c|c|c|c|}
\hline Internal Strategic Factors & Rating & Weight & Total \\
\hline \multicolumn{4}{|l|}{ Strenght } \\
\hline Few brands are marketed well by consumers & 4 & 0.25 & 1.00 \\
\hline The owner is young, passionate, sincere & 4 & 0.05 & 0.20 \\
\hline Product traceability & 4 & 0.07 & 0.28 \\
\hline Target market and focused products & 3 & 0.10 & 0.30 \\
\hline Convenience of shopping & 3 & 0.03 & 0.09 \\
\hline \multicolumn{4}{|l|}{ Weakness } \\
\hline Visual content is less attractive & 1 & 0.10 & 0.10 \\
\hline Stores opening / closing times are uncertain & 2 & 0.10 & 0.20 \\
\hline Limited human resources skill & 2 & 0.03 & 0.06 \\
\hline Troubleshoot performance issues & 2 & 0.12 & 0.24 \\
\hline Use of the latest technology & 1 & 0.15 & 0.15 \\
\hline Total & & 1.00 & 2.62 \\
\hline
\end{tabular}

Rating Information: 4 (Main Strength), 3 (Minor Strength), 2 (Minor Weakness), 1 (Main Weakness) 


\section{External Environmental Analysis}

This analysis is carried out through PESTEL (Politic, Economic, Social, Technology, Environment, Legal) and the business environment with the 5 Forces Porter approach (Competitors, Suppliers, Production, Newcomers, Buyers). The factors analyzed also refer to the results of the gap analysis related to external environmental conditions, such as the development of information technology facilities, market reach, service quality, and promotional activities. The weighting results show that the major opportunity for Cultive Apparel lies in improving infrastructure, people's consumptive lifestyles, increasing internet users, price compatibility with suppliers, and high consumer loyalty. Based on the analysis results obtained, five strategic factors that pose a threat are the number of distributions, suppliers selling retail, suppliers holding large discounts, high minimum order costs, and price wars. Based on the identification results, an EFE (External Factors Analysis) Matrix was created based on the concept of Wheelen and Hunger (2012). The results of the EFE Matrix analysis are shown in Table 2.

Table 2 shows that Cultive Apparel has an EFE value of 3.40, which means the company has high external opportunities. In other words, companies have the opportunity to take advantage of existing opportunities and minimize the negative influence from the external side. The biggest opportunity is price compatibility with suppliers and consumer loyalty $(0.20)$. The biggest threats are suppliers conducting direct retail sales and price wars $(0.80)$.

\section{IE Matrix}

The analysis results obtained from the IFE Matrix and the EFE Matrix are then inputted into the IE Matrix to determine the general condition of the company and the strategy that should be used. The results obtained are as shown in Figure 4. In the figure, it can be seen that currently Cultive Apparel is in quadrant II, meaning that the company is in a growing and developing condition (grow and build). Companies in this quadrant need to seriously evaluate their approach to the market. There are two strategic given in this quadrant. First, an intensive strategy, namely a strategy carried out to increase the company's competitiveness. This strategy includes market penetration, market development, and product development. Second, the integrative strategy, namely the strategy the company takes to increase cooperation or alliances with distributors, suppliers and competitors. This strategy includes backward integration strategies, forward integration (cooperation with distributors or retailers), and horizontal integration (cooperation with similar companies).

Table 2. EFE Matrix of cultive apparel

\begin{tabular}{lccc}
\hline External Strategic Factors & Rating & Weight & Total \\
\hline Opportunity & & & \\
Price compatibility with suppliers & 4 & 0.05 & 0.20 \\
The lifestyle of the consumptive society & 3 & 0.05 & 0.15 \\
Internet users are increasing & 3 & 0.05 & 0.15 \\
Consumer loyalty & 4 & 0.05 & 0.20 \\
Improved infrastructure that triggers economic growth & 2 & 0.07 & 0.14 \\
Threat & & & \\
Suppliers make direct retail sales & 4 & 0.20 & 0.80 \\
Suppliers hold huge discounts & 3 & 0.20 & 0.60 \\
Price war & 4 & 0.20 & 0.80 \\
The high level of distro competition & 2 & 0.03 & 0.06 \\
High minimum order fees & 3 & 0.10 & 0.30 \\
Total & & 1.00 & 3.40 \\
\hline
\end{tabular}




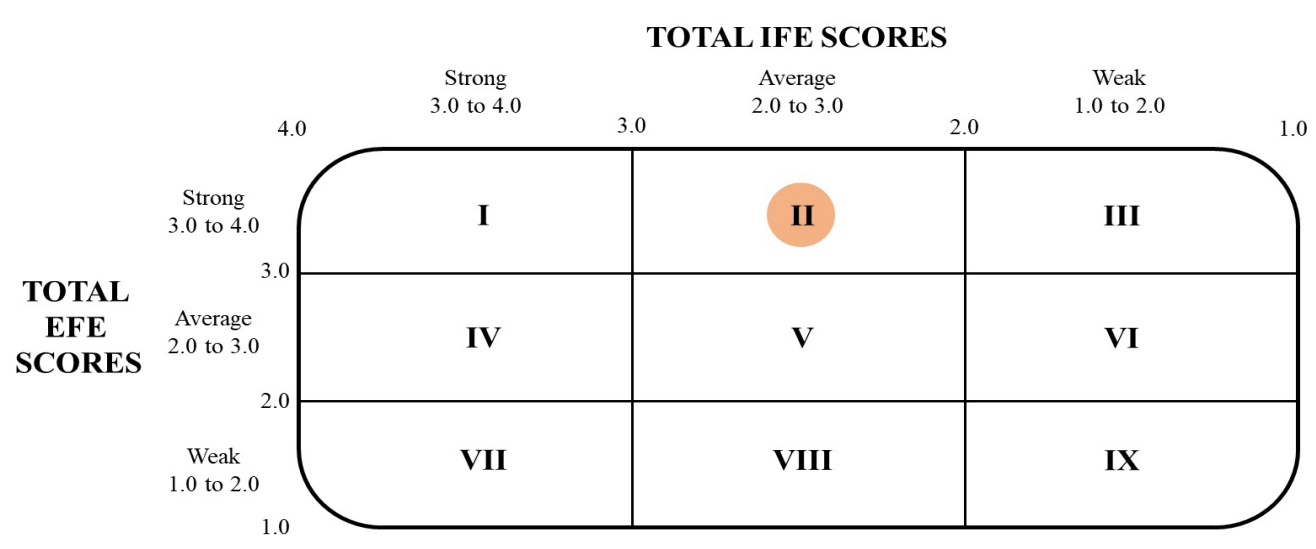

Figure 4. IE Matrix of cultive apparel

The efforts to implement the strategic recommendations need to be adjusted to the ability and availability of resources currently owned by Cultive Apparel. This is because each strategy adopted will require costs and an allocation of company resources. To avoid inefficient spending, a business strategy needs to be chosen so that the allocated resources can be maximized. The selection of the two strategic recommendations is based on the objectives of each strategy. In this case, the intensive strategy focuses on utilizing the company's resources to increase competitiveness. Meanwhile, the integrative strategy focuses on how companies collaborate externally by using their existing resources. The initial steps for implementing the strategy can be started from the internal side. The results can be used as capital for implementing an integrative strategy or forging business cooperation with various parties. The company can focus on utilizing the internet as a medium to increase the intensity of market development. Ahyuna et al. (2013) stated that the internet is very effective to be used as a channel for marketing clothing products. The Internet can be a media promotion (sales promotion), advertising, direct marketing, and personal selling. Cultive Apparel needs to choose a focus for digital transformation strategies that will be carried out on three intensive strategy choices, namely market penetration, market development, or product development.

\section{Formulation Business Strategies}

The formulation of a business strategy is carried out using the QSPM matrix. The choice of strategy based on the IE Matrix is an intensive strategy. This strategy is divided into 3 (three), namely market penetration, market development, and product development. Each strategy choice is then analyzed based on factors in the business environment. The value given is in the form of Attractiveness Value (AS) to develop the Cultive Apparel digital business. The AS value is then multiplied by the weight value for each factor to see the Total Attractiveness Scores (TAS). The highest TAS value is the result of the main strategy formulation recommended for the company. Based on this assessment criteria, the results show that business digitalization transformation needs to be focused on developing the market with the highest TAS score of 5.52 (Table 3).

Market development strategies are obtained based on QSPM matrix analysis. It is in line with Idah and Pinilih's (2019) research on the priority strategy used to develop the recommended digitalization of MSMEs is to increase market share in Indonesia. The company should be focus to take advantage of the internet in developing markets. In the current condition, the market owned by the company is very limited, which is only around the Cikarang area. Fornari et al. (2018) stated online retailers are able to become market leaders and fundamentally influence market dynamics. Market development can be started by companies by targeting potential areas, namely areas that are the highest internet users. Septania (2017) states that Java Island is the region with the highest internet users, reaching $58.08 \%, 19.05 \%$ in Sumatra, and $7.97 \%$ in Kalimantan.

Suharjo et al. (2020) declare that digital marketing strategies should be focused on improving the performance of digital marketing through evaluations of products marketed, product selling prices, distribution channels, and promotional activities carried out by MSMEs. Cultive Apparel needs to focus and explore the social media used. They have previously used Instagram, Facebook, and Twitter but they are not well managed. Based on this result, the digitalization strategy 
to develop online markets can be done through a paid media strategy. Paid media is a strategy that is carried out by utilizing paid media to carry out advertisements. The advantage of this strategy is that it can reach a very broad market. This strategy is carried out to increase exposure and brand awareness so that it can increase traffic or visits and sales through the media used by the company. To increase the effectiveness of this strategy, the company also needs to do a media owned strategy. Owned media strategy is a digitalization strategy by opening or owning a company website or social media. This strategy is used as a strategy to support the emergence of traffic or visits from advertisements that are displayed. According to Jayson et al. (2018), both of them has a positive impact on the company's long-term sales growth. The positive impact created by these two strategies has resulted in earned media, namely media that was formed due to the response from customers. Those are need to be carried out by considering the largest target market (Kuncoro dan Santoso, 2018).

\section{Managerial Implications}

Levina and Yavetz (2015) explain that the maturity of MSMEs in using internet marketing depends on the globalization of companies, social skills, and security between countries. Based on this understanding and the research results obtained, the managerial implications given are:

\section{Improve digital business infrastructure}

The transformation of a conventional business into a digital business needs to be supported by an adequate supply of facilities and infrastructure, both in quality and quantity. Some of the facilities that need to be prepared include computers and the availability of a stable internet network.

Table 3. QSPM matrix of cultive apparel

\begin{tabular}{|c|c|c|c|c|c|c|c|}
\hline \multirow[t]{2}{*}{ Key Strategic Factors } & \multirow[t]{2}{*}{ Weight } & \multicolumn{2}{|c|}{$\begin{array}{c}\text { Market } \\
\text { Penetration }\end{array}$} & \multicolumn{2}{|c|}{$\begin{array}{c}\text { Market } \\
\text { Development }\end{array}$} & \multicolumn{2}{|c|}{$\begin{array}{c}\text { Product } \\
\text { Developmen }\end{array}$} \\
\hline & & AS & TAS & AS & TAS & AS & TAS \\
\hline \multicolumn{8}{|l|}{ Strength } \\
\hline Some brands are marketed well by manufacturers & 0.25 & 3.00 & 0.75 & 4.00 & 1.00 & 3.00 & 0.75 \\
\hline The owner is young. passionate. sincere & 0.05 & 2.50 & 0.13 & 3.00 & 0.15 & 3.00 & 0.15 \\
\hline Product traceability (easy to get) & 0.07 & 3.00 & 0.21 & 3.50 & 0.25 & 3.00 & 0.21 \\
\hline Target market and focused products & 0.10 & 3.50 & 0.35 & 3.50 & 0.35 & 3.00 & 0.30 \\
\hline A convenient place to shop & 0.03 & 1.50 & 0.05 & 3.00 & 0.09 & 3.00 & 0.09 \\
\hline \multicolumn{8}{|l|}{ Weakness } \\
\hline Visual content is less attractive & 0.10 & 1.50 & 0.15 & 2.50 & 0.25 & 3.00 & 0.30 \\
\hline Stores opening / closing times are uncertain & 0.10 & 1.50 & 0.15 & 1.50 & 0.15 & 2.00 & 0.20 \\
\hline Human resource limitations & 0.03 & 1.50 & 0.05 & 2.00 & 0.06 & 2.00 & 0.06 \\
\hline Troubleshoot performance issues & 0.12 & 2.00 & 0.24 & 2.00 & 0.24 & 2.00 & 0.24 \\
\hline Use of the latest technology & 0.15 & 1.50 & 0.23 & 1.00 & 0.15 & 1.50 & 0.23 \\
\hline \multicolumn{8}{|l|}{ Opportunity } \\
\hline Price compatibility with suppliers & 0.05 & 2.50 & 0.13 & 3.00 & 0.15 & 3.00 & 0.15 \\
\hline The lifestyle of the consumptive society & 0.05 & 3.00 & 0.15 & 3.00 & 0.15 & 3.00 & 0.15 \\
\hline Supplier loyalty & 0.05 & 3.00 & 0.15 & 3.50 & 0.18 & 3.50 & 0.18 \\
\hline Consumer loyalty & 0.05 & 3.00 & 0.15 & 3.50 & 0.18 & 3.00 & 0.15 \\
\hline Economic growth & 0.07 & 3.00 & 0.21 & 3.00 & 0.21 & 3.50 & 0.25 \\
\hline \multicolumn{8}{|l|}{ Threat } \\
\hline Suppliers make direct retail sales & 0.20 & 3.50 & 0.70 & 2.50 & 0.50 & 2.50 & 0.50 \\
\hline Suppliers hold huge discounts & 0.20 & 3.50 & 0.70 & 2.50 & 0.50 & 2.50 & 0.50 \\
\hline Price war (dumping) & 0.20 & 3.50 & 0.70 & 3.00 & 0.60 & 3.00 & 0.60 \\
\hline The high level of distro competition & 0.03 & 2.50 & 0.08 & 2.50 & 0.08 & 2.00 & 0.06 \\
\hline High minimum order fees & 0.10 & 2.50 & 0.25 & 3.00 & 0.30 & 3.50 & 0.35 \\
\hline Total & & & 5.50 & & 5.52 & & 5.41 \\
\hline
\end{tabular}


Improve the operational capabilities of employees

Customer satisfaction in digital marketing leads to service quality, customer satisfaction with certain service experiences will lead to an evaluation or overall attitude towards service quality at all times (Moriuchi and Takahashi, 2018; Rezaei et al. 2018; Chiang, 2018). Meanwhile, the digital business should be supported by knowledge of understanding the use of the internet as a product communication tool, knowledge of target consumers that businesses want to achieve and knowledge of using digital marketing to expand the market. For this reason, in order to improve the company's business performance, efforts are needed to increase the expertise possessed by employees.

\section{Develop market segments}

The current target market for Cultive Apparel is young people who enjoy metal music. For this reason, articles made are always on the theme of horror in order to suit this target market. To carry out market development, this target needs to be expanded following the direction of company development, namely adjusting to the culture of the business owner. As an initial step in developing geographic market segments, companies can target areas with good internet coverage, such as Java and Sumatra.

\section{Increase the intensity of digital marketing}

Increasing the intensity of digital marketing can further bind the relationships that have been formed with loyal customers. In addition, digital marketing activities to increase market expansion also need to be carried out intensively. This is done in order to build new market niches. Another goal of increasing the intensity of digital marketing is to increase the company's brand image. In this case, the majority company allocated up to $25 \%$ of the total marketing budget to finance digital tools (Ziółkowska, 2021).

\section{CONCLUSIONS AND RECOMMENDATIONS}

\section{Conclusions}

Five factors must be considered in the gap analysis, namely market reach, IT facilities, organizational management, service quality, and promotional activities. Promotion activities get the biggest gap score, namely 2.2. The second-highest gap factor is IT facilities, namely 2.0. The company's weakness lies in its limited human resources. The greatest opportunities that can be exploited are price compatibility with suppliers and high customer loyalty. The company's biggest threat is the existence of suppliers selling direct retail to consumers and the occurrence of price wars. IE matrix shows the position of the company is in quadrant II and the recommended strategy is an intensive strategy. The strategy was chosen because internally the company's revenue is currently decreasing. In this condition, the company needs to establish a focus on business strategy so that its resources can be utilized optimally and more efficiently (not a lot of waste). In this condition, the internet is needed as a medium to increase the intensity of the company's market development. The QSPM analysis of each strategy choice indicates that the transformation of the Cultive Apparel business digitization needs to be focused on market development. The TAS score for this alternative strategy is 5.52 .

\section{Recommendations}

The first research suggestion is to analyze a business model that can be used for Cultive Apparel. Further research suggestions that can be given are to analyze the market potential and marketing of Cultive Apparel products using digital media. This study is aimed at analyzing and calculating market potential, sales, and forecasting the profits that can be obtained by the company and measuring consumer response to products.

\section{REFERENCES}

Aghekyan M. 2009. The Role of Product Brand Image and Online Store Image On Perceived Risks and Online Purchase Intentions. Alabama:Auburn Universities.

Ahyuna, Hamzah DM, Najib M. 2013. Pemanfaatan internet sebagai media promosi pemasaran produk lokal oleh kalangan usaha di Kota Makassar. Jurnal Komunikasi KAREBA 2(1):3040.

Aina QA, Suwarsinah KH, Bahanuddin. 2017. Faktorfaktor yang mempengaruhi kinerja usaha mompreneur (studi kasus:komunitas bunda online) [tesis]. Bogor:Institut Pertanian Bogor.

Anderson D, Anderson LA. 2010. Beyond Change 
Management How to Achieve Breakthrough though Conscius Change Leadership. Ed ke-2. San Fancisko:Pfeiffer.

Astuti PR, Kartono, Rahmadi. 2020. Pengembangan UMKM melalui digitalisasi teknologi dan integrasi akses permodalan. Jurnal Penelitian dan Pengabdian Masyarakat 8(2):248-256.

Barlian KJ. 2018. Ini tren prediksi e-commerce versi shopback. https://kumparan.com/. [27 Februari 2019].

Bismala L. 2016. Model manajemen usaha mikro kecil dan menengah (UMKM) untuk meningkatkan efektivitas usaha kecil menengah. Jurnal Entrepreneur dan Entrepreurship 5(1):19-25.

Chiang WY. 2018. Applying data mining for online CRM marketing strategy:An empirical case of coffee shop industry in Taiwan. British Food Journal 120(3):665-675.

David FR. 2009. Strategic Management. Edisi Bahasa Indonesia. Dono Sunardi, penerjemah. Jakarta:PT Salemba Empat dan Pearson Education, Inc.

Fadhilah AN, Subriadi AP. 2019. The Role of IT on Firm Performance. Procedia Computer Science 161 (2):258-265.

Fornari D, Grandi S, Fornari E. 2018. Retailing 4.0:The new era of e-commerce in fast moving consumer goods, symphonya. Emerging Issues in Management (17)2:77-90.

Gil-Gomez H, Guerola-Navarro V, Oltra-Badenes R, Lozano-Quilis JA. 2020. Customer relationship management:Digital transformation and sustainable business model innovation. Econ. Res. Ekon. Istraživanja 33(2):2733-2750.

Idah MY, Pinilih M. 2019. Strategi pengembangan digitalisasi UMKM. Pengembangan Sumberdaya Perdesaan dan Kearifan Lokal Berkelanjutan IX 9(1):195-204.

Jayson R, Block PM, Chen Y. 2018. How sinergy effects of paid and digital owned media influence brand sales. Considerations for marketers when balancing media spend. Journal of Advertising Research 58(1):77 - 89 .

Kencana BRM. 2018. Mendag Mendorong Transaksi Online dan Offline agar Perkuat Transaksi Bisnis. https://www.liputan6.com/bisnis/read/3815750/. [20 Agust 2020].

Kholiq N, Yudho P, Purnomo H. 2017. Pengaruh kualitas produk, harga dan lokasi terhadap kepuasan pelanggan di distro east project di Kediri tahun 2017. Jurnal Simki-Economic 1 (2):1-7.

Kominfo. 2017. Kuliner, Kriya dan Fashion,
Penyumbang Terbesar Ekonomi Kreatif.https:// www.kominfo.go.id/. [20 Agust 2020].

Kuncoro H, Santoso SSD. 2018. Analisis strategi pemasaran pada usaha clothing line sinkkink pride. Jurnal Ecodunimika. 1(3):1-7.

Levina O, Yavetz VI. 2015. E-visibility maturity model:A tool for assessment and comparison of individual firms and sets of firms in e-business. Electronic Commerce Research and Applications. 14(6):480-498.

Moriuchi E, Takahashi I. 2018. An empirical investigation of the factors motivating Japanese repeat consumers to review their shopping experiences. Journal of Business Research 82(1):381-390.

Rachmana FF. 2019. Banyak kios di Glodok dan Tanah Abang tutup, ini analisa pengusaha. https:// finance.detik.com/. [09 Sept 2020].

Rahab. 2009. Penerapan manajemen merek pada usaha kecil dan menengah (UKM). Jurnal Bisnis dan Ekonomi (JBE) 16(1):18 - 25.

Rauter R, Jonker J, Baumgartner RJ. 2017. Going one's own way:Drivers in developing business models for sustainability. Journal of Clean. Prod. 140 (3):144-154.

Rezaei S, Chandran R, Oh Y M. 2018. Pre-Purchase User Perceptions of Attributes and Post-Purchase Attitudes in Building Successful Online Retail Promotional Strategies. In Digital Marketing and Consumer Engagement:Concepts, Methodologies, Tools, and Applications (pp. 368-382). IGI Global.

Samuel BS, Sarprasatha J. 2016. Entrepreneurship in social-media services in Oman:A socioeconomic scanning of the sultanate. Asian Social Science 12(1):138-148.

Septania CR. 2017. Daerah di Indonesia yang Paling Rajin Internetan https://tekno.kompas.com/. [31 Jan 2021].

Shabbir MS, Ghazi MS, Mehmood A. 2016. Impact of social media applications on small business entrepreneurs. Arabian Journal of Business and Management Review 6 (1):203-205.

Slamet R, Nainggolan B, Roessobiyanto, Ramdani H, Hedriyanto A, Ilma LL. 2016. Strategi pengembangan UKM digital dalam menghadapi era pasar bebas. Jurnal Manajemen Indonesia. 16(2):136-147.

Suharjo RA, Fahmi I, Hannan S. 2020. Digital Marketing Strategy of Small and Medium Enterprises for Snack in Bogor City. Jurnal Manajemen \& 
Agribisnis 17(1):74-85

Wheelen TL, Hunger JD. 2012. Strategic Management and Bussiness Policy:Toward Global Sustainability (13th Edition). New York:Pearson.
Ziółkowska MJ. 2021. Digital transformation and marketing activities in small and medium-sized enterprises. Journal of Sustainability 13(5):116. 